\title{
Lateral Cephalometric Study in Adult Bulgarians with Normal Occlusion
}

\author{
Katya G. Todorova-Plachiyska, Mariya G. Stoilova-Todorova \\ Department of Orthodontics, Faculty of Dental Medicine, Medical University of Plovdiv, Plovdiv, Bulgaria
}

\section{Correspondence:}

Katya G. Todorova-Plachiyska, Department of Orthodontics, Faculty of Dental Medicine, Medical University of Plovdiv, 3 Hristo Botev Blvd., 4000 Plovdiv, Bulgaria

E-mail: dr.katya.todorova@gmail. com

Tel: +359888098337

Received: 06 Jan 2017

Accepted: 07 July 2017

Published Online: 31 Aug 2017

Published: 30 March 2018

Key words: Bulgaria, cephalometric norms, gender difference

Citation: Todorova-Plachiyska KG, Stoilova-Todorova MG. Lateral cephalometric study in adult Bulgarians with normal occlusion. Folia Med (Plovdiv) 2018;60(1):141-6.

doi: 10.1515/folmed-2017-0072
Orthodontic treatment is effective when the facial and cephalometric characteristics of the ethnic background of patients are considered because the normal measurements for one group are not necessarily normal for another group. It is important to develop individual standards for each population. Different racial groups must be treated according to their own characteristics.

The aim of this study was to establish a cephalometric standard of the cranial bases and jaw bases for Bulgarian population and to find the differences between males and females. The pilot study included 390 adult Bulgarians. Of these, 90 cases with intact dentitions, harmonious faces and Angle Class I occlusion who have not received orthodontic treatment, were purposefully selected. Lateral cephalometric radiographs of the selected subjects were taken. Six linear/angular measurements combining sagittal parameters selected form Steiner (ANB angular indicator), Schwarz ( $\mathrm{S}-\mathrm{N}, \mathrm{Ba}-\mathrm{N}, \mathrm{A}^{1}-\mathrm{PNS}, \mathrm{Go}-\mathrm{APMan}$ linear indicators) and Jacobson (WITS-linear indicator) analysis were recorded. Student's t-test with $5 \%$ significance level was used for data analysis (means, standard deviations, maximum and minimum values) and to assess gender differences. A gender-based cephalometric analysis of indicators found that there are statistically significant differences. Only the ANB angular parameter did not show any statistically significant difference between genders. The cephalometric variables measured in this study were significantly different between the genders except for angle ANB, and they were higher in boys. The results of our study confirm previous research on the topic presented in specialized literature.

\section{BACKGROUND}

Analysis of lateral cephalometric head films is an additional diagnostic aid used to determine the relationship of the skeletal and dental structures. Cephalometry in orthodontics has been used extensively to study facial form and treatment planning. It is also used to assess treatment progress and craniofacial growth, to predict growth for individual patients, and for other tasks in orthodontic research.

Cephalometric norms can be invaluable to dental practitioners in determining patient; they are based on factors such as age, sex, size, and race. In fact it is important to compare a patient's cephalometric findings with the norms for his or her ethnic group in order to achieve accurate diagnostic evaluation, while considering his or her treatment goals and needs.

Due to the ethnic variability of skull morphology it is important to compare a patient's cephalomet- ric findings with the norms for his or her ethnic group for in order to gain an accurate diagnostic evaluation. Only the Causcasian standards are available however, ethnic difference that exists, is well known. Unfortunately norm values for European- Bulgarian are lacking. The studies indicate that normal measurements for each group should not be considered normal for every other race or ethnic group. Therefore, it is important to develop individual standards for each population. Different racial groups must be treated according to their own characteristics.

The cephalometric analysis should evaluate the position of the maxilla and mandible with that of the cranial base and the relationship of the maxilla and mandible to one another. Cephalometric standards are not available for the local Bulgarian population with which patients can be compared or assessed during treatment. Hence, there is an 
urgent need to establish the normal standards of Bulgarian population.

\section{AIM}

The objectives of this research are: (1) to establish cephalometric standards for lateral x-rays of Bulgarian adolescent that can be used as baseline data for diagnostic purposes and planning orthodontic treatment; (2) to identify sex differences between Bulgarian males and females.

\section{MATERIALS AND METHODS}

Of the 390 subjects included in the study, 90 cases met the evaluation criteria. Study participants were students referred from the Dental Faculty of Plovdiv and Medical college of Plovdiv between 19 to 26 years of age.

The 90 cases (44 males and 46 females) were chosen according to the following criteria: patients with class I dental and skeletal malocclusion who presented class I molar relationship with normal overjet and overbite, mild or no tooth crowding or spacing, harmonious faces, intact dentitions and no history of orthodontic treatment.

Lateral cephalometric radiographs of the selected subjects were taken. The study was approved by the institutional Ethics in Human Research Committee (protocol 2106/2014).

The lateral cephalograms of 90 study participants were analysed. Cephalometric tracings were performed on standard acetate paper (17.5 x 17.5 $\mathrm{cm}$ and $0.07 \mathrm{~mm}$ thickness) with a $0.3-\mathrm{mm}$ graphite mechanical pencil, transparent ruler to the nearest $0.5 \mathrm{~mm}$, protractor to the nearest $0.1^{\circ}$, template, adhesive tape and illuminator. All tracings were done by the investigator in a darkened room. Tracings were performed twice at a minimum interval of 10 days aiming to eliminate possible investigator's error.

The results obtained, were tabulated and statistically analyzed. Database were processed with statistical package SPSS $19.0^{1}$ (IBM Corp. 2010). The level of significance was set at $\mathrm{p}<0.05$. A paired-sample t-test and ANOVA were used to evaluate statistically the findings. Means, standard deviations, and analyses of covariance, adjusted for age and sex, were derived.

We studied 90 lateral cephalometric radiographs of adult Bulgarians. The cephalograms were analyzed using Steiner (ANB angular indicator), Schwarz (S-N, Ba-N, A ${ }^{1}-\mathrm{PNS}$, Go-APMan linear indicators) and Jacobson (WITS-linear indicator) analyses. The measured cephalometric landmarks are presented in Fig. 1 and Table 1.

Using these landmarks the following linear and angular indicators were made for the subjects (Fig. 1): ANB - angular indicator for assessment of the sagittal relationship between the jaws; WITSlinear indicator for assessment of the relationship between the jaws which is traced according to occlusal plane constructed between the midpoint of the first molars mesial cusps overlap and the midpoint of the incisor overbite; $\mathrm{S}-\mathrm{N}$ and $\mathrm{Ba}-\mathrm{N}-$ linear measurements for assessment of the cranial base; $\mathrm{A}^{1}$-PNS-linear indicator for assessment of the maxillary base; Go- APMan - linear indicator for assessment of mandibular base.

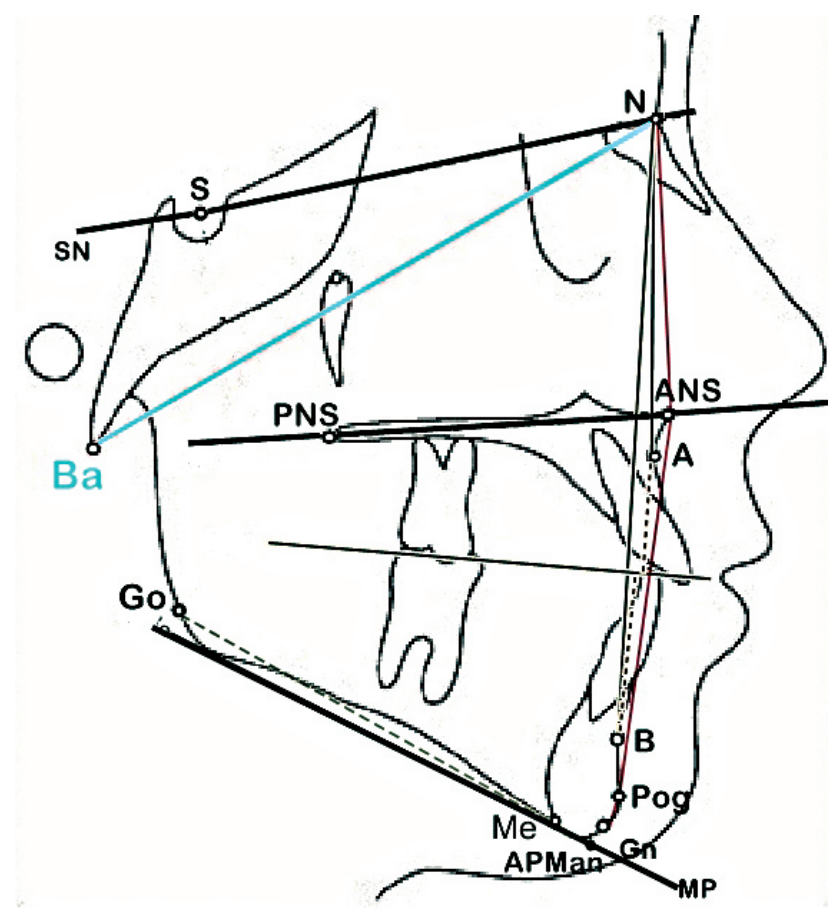

Figure 1. Cephalometric landmarks and indicators.

\section{RESULTS}

We found normal occlusal and sagittal relationships in $90(23.8 \%)$ of the monitored subjects. The gender diversity in our sample was 44 men and 46 women. The average age of the total sample was $22.4 \pm 0.26$ years (Fig. 2).

The Kolmogorov-Smirnov test showed that the data were normally distributed (Table 2).

The results allowed us to obtain the reference values of cephalometric indicators for Bulgarian population. 
Table 1. Definitions of used cephalometric indicators

\begin{tabular}{cl}
\hline $\begin{array}{c}\text { Cephalometric } \\
\text { Landmark }\end{array}$ & \multicolumn{1}{c}{ Definition } \\
\hline Ba & $\begin{array}{l}\text { the median point of the anterior margin of the foramen magnum located by following the } \\
\text { image of the slope of the inferior border of the basilar part of the occipital bone to its pos- } \\
\text { terior limit }\end{array}$ \\
the center of sella turcica \\
the most anterior limit of suture nasofrontal \\
ANS & $\begin{array}{l}\text { anterior nasal spine } \\
\text { posterior nasal spine } \\
\text { the point at the deepest midline concavity on the maxilla between alveolar process and } \\
\text { point ANS } \\
\text { anterior point for determining maxillary length, constructed by dropping a perpendicular } \\
\text { line from A point to palatal plane }\end{array}$ \\
B & $\begin{array}{l}\text { the point at the deepest midline concavity on the mandibular symphysis between } \\
\text { infradentale and Pog } \\
\text { the most anterior point of the bony chin in the median plane }\end{array}$ \\
Pog & $\begin{array}{l}\text { anterior point for determining mandibular length, constructed by dropping a perpendicular } \\
\text { line from Pog to the mandibular plane }\end{array}$ \\
the most outward point on the angle formed by the ramus and body of the mandible
\end{tabular}

All skeletal components were studied together with the total sample (Table 3) and separated by gender (Table 4).

Table 3 shows the mean values, standard deviations, maximum and minimum values of cephalometric indicators for each parameter of the 90 subjects with completed growth and normal sagittal relationships.

The mean value of angle ANB is $2.39 \pm 0.11^{\circ}$ and for the WITS appraisal (AO - BO) it is $0.98 \pm$ $0.19 \mathrm{~mm}$. Measurements confirm that the monitored subjects are with normal sagittal relationships of both jaws (I skeletal class) and can be used in the present study.

The mean value of base of the skull $\mathrm{Ba}-\mathrm{N}$ for Bulgarian population is $111.30 \pm 0.63 \mathrm{~mm}$ and for the anterior cranial base $\mathrm{S}-\mathrm{N}$ is $72.80 \pm 0.43 \mathrm{~mm}$.

The $t$-test was used to evaluate the differences between the genders. Based on the gender we establish statistically significant differences (Table 4).

The results showed that except for the angle ANB, every other variable was significantly higher in males. Class I males are larger than Class I females in terms of overall maxillary length $\left(\mathrm{A}^{1}-\mathrm{PNS}\right)$. Corpus mandibular length (Go-APMan) were found to be shorter in females. Based on the gender we establish statistically significant differences. The larger skeletal bases of the cranium in males can be associated to sexual dimorphism.

The gender differences are more pronounced in relation to cephalometric indicator $\mathrm{AO}-\mathrm{BO}$. The cephalometric indicator $\mathrm{AO}-\mathrm{BO}$ was significantly higher in males $(1.57 \pm 0.20 \mathrm{~mm})$ compared to females $(0.40 \pm 0.30 \mathrm{~mm})$.

Only the ANB angular parameter does not show any statistically significant difference between genders (Table 2). ANB angle is a resultant parameter of angles SNA and SNB and is not affected by gender.

\section{DISCUSSION}

Gender differences in our study were found to be statistically significant, which is consistent with the finding of Athanasiou ${ }^{2}$, Enlow $^{3}$, Gianelly ${ }^{4}$, Graber ${ }^{5}$, and Langlade. ${ }^{6}$ Females generally have smaller dimension of most indicators of skeletal morphology as confirmed by Downs ${ }^{7}$ and Rakosi. ${ }^{8}$ Our results confirmed the conclusion of Bishara ${ }^{9}$, Jacobson ${ }^{10}$, and Langlade ${ }^{6}$ about WITS (AO-BO) assessment and showed sexual dimorphism with males significantly more than females. Our study agrees with previ- 


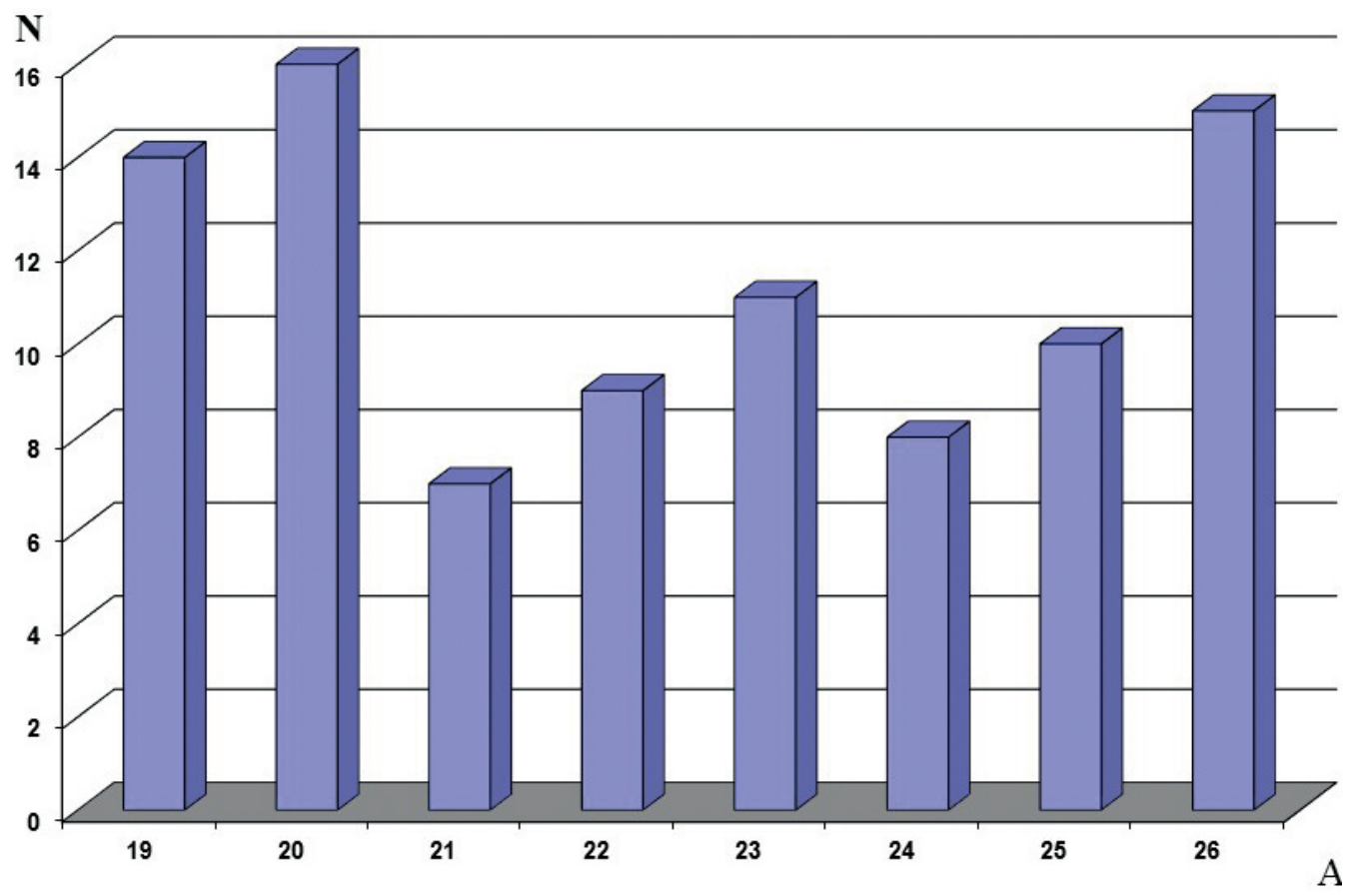

Figure 2. Distribution by age in the total sample.

Table 2. Distribution of cephalometric indicators in the total sample

\begin{tabular}{|c|c|c|c|c|c|c|c|}
\hline Cephalom & c indicators & ANB $\left({ }^{\circ}\right)$ & $\begin{array}{c}\text { AO-BO } \\
\text { (Wits) } \\
(\mathrm{mm})\end{array}$ & $\begin{array}{l}\mathrm{S}-\mathrm{N} \\
(\mathrm{mm})\end{array}$ & $\begin{array}{l}\mathrm{Ba}-\mathrm{N} \\
(\mathrm{mm})\end{array}$ & $\begin{array}{c}\mathrm{A}^{1} \text {-PNS } \\
(\mathrm{mm})\end{array}$ & $\begin{array}{c}\text { Go-APMan } \\
(\mathrm{mm})\end{array}$ \\
\hline & & 90 & 90 & 90 & 90 & 90 & 90 \\
\hline Normal & Mean & 2.3967 & 0.9778 & 72.8056 & 111.3056 & 55.9000 & 78.9889 \\
\hline Parameters & $\mathrm{StD}$ & 1.08684 & 1.83583 & 4.13310 & 6.03021 & 3.43331 & 3.36620 \\
\hline & Absolute & 0.120 & 0.138 & 0.097 & 0.111 & 0.077 & 0.110 \\
\hline $\begin{array}{l}\text { Most Extreme } \\
\text { Differences }\end{array}$ & Positive & 0.120 & 0.069 & 0.097 & 0.087 & 0.077 & 0.110 \\
\hline & Negative & -0.119 & -0.138 & -0.060 & -0.111 & -0.063 & -0.077 \\
\hline Kolmogorov-Sn & iov Z & 1.140 & 1.311 & 0.924 & 1.053 & 0.727 & 1.042 \\
\hline Asymp. Sig. (2 & led) & 0.148 & 0.064 & 0.360 & 0.218 & 0.665 & 0.228 \\
\hline
\end{tabular}

Table 3. Cephalometric features of I skeletal class for Bulgarian subjects ( $n=90)$

\begin{tabular}{lcccc}
\hline Cephalometric indicators & Min & Max & mean \pm SE & $\mathbf{9 5 \%}$ CI \\
\hline ANB & 0.00 & 4.00 & $2.39 \pm 0.11$ & {$[2.19 ; 2.62]$} \\
AO - BO & 1.00 & 4.00 & $0.98 \pm 0.19$ & {$[0.59 ; 1.36]$} \\
S - N & 64.00 & 82.00 & $72.80 \pm 0.43$ & {$[71.94 ; 73.67]$} \\
A $^{1}-$ PNS & 50.00 & 64.00 & $55.90 \pm 0.36$ & {$[55.18 ; 56.62]$} \\
Ba - N & 101.00 & 123.50 & $111.30 \pm 0.63$ & {$[110.04 ; 112.57]$} \\
Go - APMan & 71.00 & 88.00 & $78.98 \pm 0.35$ & {$[78.28 ; 79.69]$} \\
\hline
\end{tabular}


Table 4. A gender-based analysis of indicators

\begin{tabular}{|c|c|c|c|c|c|}
\hline Indicators & Gender & $\mathbf{N}$ & mean $\pm \mathrm{SE}$ & $\mathbf{T}$ & $\mathbf{P}$ \\
\hline \multirow{2}{*}{ ANB $\left({ }^{\circ}\right)$} & Male & 44 & $2.55 \pm 0.18$ & \multirow{2}{*}{1.36} & \multirow{2}{*}{0.05} \\
\hline & Female & 46 & $2.24 \pm 0.13$ & & \\
\hline \multirow{2}{*}{$\mathrm{AO}-\mathrm{BO}(\mathrm{mm})$} & Male & 44 & $1.57 \pm 0.20$ & \multirow{2}{*}{3.22} & \multirow{2}{*}{0.002} \\
\hline & Female & 46 & $0.40 \pm 0.30$ & & \\
\hline \multirow{2}{*}{$\mathrm{S}-\mathrm{N}(\mathrm{mm})$} & Male & 44 & $75.43 \pm 0.52$ & \multirow{2}{*}{7.51} & \multirow{2}{*}{0.0001} \\
\hline & Female & 46 & $70.29 \pm 0.44$ & & \\
\hline \multirow[b]{2}{*}{$\mathrm{A}^{1}-\mathrm{PNS}(\mathrm{mm})$} & Male & 44 & $57.74 \pm 0.47$ & \multirow{2}{*}{5.1} & \multirow{2}{*}{0.0001} \\
\hline & Female & 46 & $54.14 \pm 0.39$ & & \\
\hline \multirow{2}{*}{$\mathrm{Ba}-\mathrm{N}(\mathrm{mm})$} & Male & 44 & $114.69 \pm 0.76$ & \multirow{2}{*}{6.22} & \multirow[t]{2}{*}{0.0001} \\
\hline & Female & 46 & $108.06 \pm 0.74$ & & \\
\hline \multirow{2}{*}{ Go - APMan (mm) } & Male & 44 & $80.04 \pm 0.50$ & \multirow{2}{*}{3.04} & \multirow{2}{*}{0.003} \\
\hline & Female & 46 & $77.98 \pm 0.45$ & & \\
\hline
\end{tabular}

ous examination of a Bulgarian sample population showing that subjects exhibit significant gender differences in craniofacial anatomy. ${ }^{13-15}$

Our study agrees with the study of Jacobson ${ }^{10}$ and Bishara ${ }^{11}$ which showed that angle ANB had no significant difference between genders. This is resultant parameter which explains that jaws relationship and the proportions between them are relatively equal in both sexes.

The results suggest that the cephalometric measurements were correspondent to the standards stated by other investigators. ${ }^{6-8,10}$ Maxillary base length, mandibular base length and anterior cranial base were evaluated from Schwartz's ${ }^{12}$ analysis. Compaison of present study with Schwartz's analysis shows that there is a significant difference between the mean maxillary and mandibular base lengths, and these parameters are larger in our study.

The variety of craniofacial characteristics present in the different racial and ethnic groups have been investigated in several studies ${ }^{6,11,13}$, which mention the adoption of standard normality mean values for each specific group. Thus, each group should be evaluated separately according to its individual characteristics.

\section{CONCLUSION}

Sexual dimorphism is evident in young Bulgarian adults relative to linear skeletal indicators. Males showed significantly greater maxillary and mandibular length than females. Skeletal determinants of Class I malocclusions for Bulgarian population may be different from those of other population groups.

\section{REFERENCES}

1. IBM Corp. Released 2010. IBM SPSS Statistics for Windows, Version 19.0. Armonk, NY: IBM Corp.

2. Athanasiou AE. Orthodontic Cephalometry. Mosby - Wolfe; 1995.

3. Enlow DH, Hans MG. Essentials of Facial Growth. $2^{\text {nd }}$ ed. Ann Arbor: Needham Press; 2008.

4. Gianelly A. Age and sex cephalometric norms? Am J Orthod 1970;57:497-501.

5. Graber T, Vanarsdall LR, Vig K. Orthodontics: Current Principles and Techniques. Elsevier Mosby; 2005.

6. Langlade M. Diagnostic orthodontique. $2^{\text {nd }} \mathrm{ed}$. Maloine; 1981

7. Downs W. Variation in facial relationships: their significance in treatment and prognosis. Am J Orthod 1949;34:812-40.

8. Rakosi T. An Atlas and Manual of Cephalometric Radiography. $1^{\text {st }}$ ed. United States, St. Louis, Missouri: Mosby; 1982.

9. Bishara SA. Textbook of orthodontics. Saunders; 2001.

10. Jacobson A. Radiographic Cephalometry. From ba- 
sics to 3-D imaging. $2^{\text {nd }}$ ed. Quintessence Publishing Co, Inc.; 2006.

11. Bishara S, Fakl J, Peterson L. Longitudinal changes in the ANB angle and "Wits" appraisal: clinical complications. Am J Orthod 1983;84:133-9.

12. Schwartz H. A method of measuring points in spaces recorded by the Broadbent-Bolton cephalometric technique. United States, Evanston, Illinois: North Western University; 1943.

13. Krumova V, Petrunov V. Cephalometric study of adult Bulgarians with normal occlusion and harmoni- ous face. Ortodontski pregled (Sofia) 2000;2 (2):3-9.

14. Krusteva S. Transverse deviation of occlusion and facial asymmetry - models for diagnostic assessment. [PhD Thesis], Plovdiv, Bulgaria, Medical University of Plovdiv, 2011.

15. Petrunov V. Epidemiological study of malocclusions and orthodontic treatment need in Bulgarians in the period from mixed to permanent dentition. [PhD Thesis], Sofia, Bulgaria, Medical University of Sofia, 2012.

\title{
Латеральное цефалометрическое исследование болгарского населе- ния взрослого возраста с нормальной окклюзией
}

\author{
Катя Г. Тодорова-Плачийска, Мария Г. Стоилова-Тодорова \\ Кафедра ортодонтии, Факультет дентальной медицины, Медицинский университет- Пловдив, Пловдив, Болгария
}

\begin{abstract}
Адрес для корреспонденции: Катя Г. Тодорова - Плачийска, Кафедра ортодонтии, Факультет дентальной медицины, Медицинский университет- Пловдив, бул. „Христо Ботев" 3, 4000,

Пловдив, Болгария

E-mail: dr.katya.todorova@gmail. com

Tel: +359888098337
\end{abstract}

Дата получения: 06 января 2017

Дата приемки: 07 июля 2017

Дата онлайн публикации: 31 августа 2017

Дата публикации: 30 марта 2018

Ключевые слова: Болгария, цефалометрические нормы, межполовые различия

Образец цитирования: Todorova-Plachiyska KG, StoilovaTodorova MG. Lateral cephalometric study in adult Bulgarians with normal occlusion. Folia Med (Plovdiv) 2018;60(1):141-6.

doi: 10.1515/folmed-2017-0072
Ортодонтическое лечение является эффективным при учитывании фациальных и цефалометрических характеристик этнического происхождения пациентов, так как нормальные размеры для представителей одной группы не являются обязательно нормальными для представителей другой группы. Особенно важным фактором является разработка индивидуальных стандартов для каждой популяции. Различные рассовые группы должны проходить лечение в соответствии с типичными для них характеристиками.

Целью данного исследования являлось определение цефалометрического стандарта основания черепа и челюсти болгарского населения и установление различий между мужчинами и женщинами. 390 болгар взрослого возраста были обследованы для осуществления пилотного исследования. Из общего числа обследованных было отобрано 90 случаев с интактным зубным рядом, гармоничными чертами лица и окклюзией I класса по Angle, которые не проходили ортодонтическое лечение. Были сделаны латеральные рентгеновские снимки отобранных пациентов. Был осуществлён анализ шести линейных и угловых размеров, комбинирующих сагиттальных параметров, отобранных по Steiner (ANB угловой показатель), Schwarz (S-N, Ba-N, A1-PNS, Go- APMan линейные показатели) и Jacobson (WITS-линейный показатель). Был использован Т-тест Стьюдента с 5\% уровнем значимости для анализа данных (средние стоимости, стандартные отклонения, максимальные и минимальные стоимости) и для оценки межполовых различий. Только ANB угловой показатель не показал статистически значимой разницы между мужчинами и женщинами. Цефалометрические переменные, измеренные в данном исследовании, оказались в значительной степени различными для мужчин и женщин, за исключением углового ANB и были более высокими у представителей мужского пола.

Результаты нашего исследования подтверждают предыдущие исследования по теме, представленные в научной литературе. 